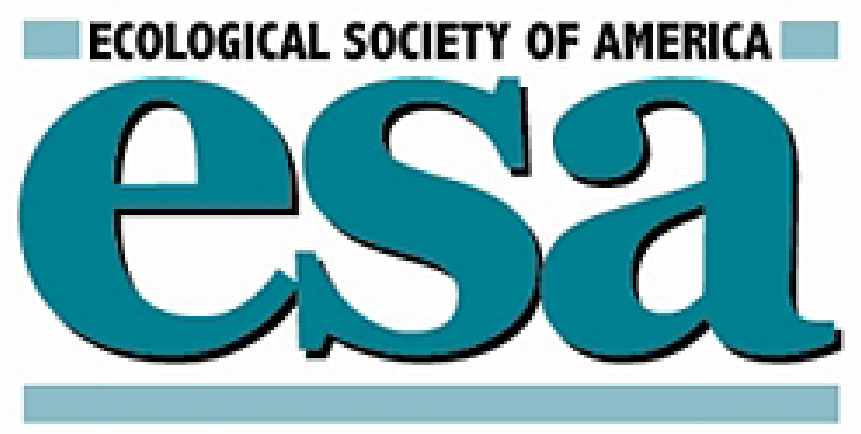

Germination Response of Legume Seeds Subjected to Moist and Dry Heat Author(s): Robert E. Martin, Robert L. Miller and Charles T. Cushwa

Source: Ecology, Vol. 56, No. 6 (Autumn, 1975), pp. 1441-1445

Published by: Ecological Society of America

Stable URL: http://www.jstor.org/stable/1934712

Accessed: 13/03/2014 10:05

Your use of the JSTOR archive indicates your acceptance of the Terms \& Conditions of Use, available at http://www.jstor.org/page/info/about/policies/terms.jsp

JSTOR is a not-for-profit service that helps scholars, researchers, and students discover, use, and build upon a wide range of content in a trusted digital archive. We use information technology and tools to increase productivity and facilitate new forms of scholarship. For more information about JSTOR, please contact support@jstor.org. 


\title{
GERMINATION RESPONSE OF LEGUME SEEDS SUBJECTED TO MOIST AND DRY HEAT ${ }^{1}$
}

\author{
Robert E. Martin, ${ }^{2}$ Robert L. Miller, ${ }^{3}$ and Charles T. Cushwa 4 \\ Virginia Polytechnic Institute State University, Blacksburg, Virginia 24060 USA
}

\begin{abstract}
Prescribed burning is used in southeastern USA to promote growth of leguminous plants which produce seed important as quail food. These seed are characterized by a hard seed coat and the ability to remain dormant but viable for a long time. This study was conducted to determine the effect of heat on germination of seed from several of these legume species. Seeds of 18 species and two varieties were subjected to moist and dry heat treatment. Moist heat increased germination in eight species and two varieties, and dry heat increased germination in seven species and two varieties.
\end{abstract}

Key words: Fire; germination; heat; legume seeds; seeds.

\section{INTRODUCTION}

Prescribed burning is an important resource management practice in the southeastern United States, particularly in the Coastal Plain area, where millions of acres of forested land are burned annually for purposes of fuel reduction, slash disposal, seedbed preparation, and improving cattle forage and wildlife habitat. Burning for any of these reasons usually accomplishes some of the others, although vegetative changes which follow forest fire may affect the habitat of various species of wildlife either beneficially or detrimentally.

Much of the flora and fauna of the Coastal Plains evolved in the presence of frequent burning and their species are referred to as fire species. The understory in many pine forests in the area is maintained in an early stage of secondary succession by frequent burning. Leguminous plants are common understory species in the longleaf (Pinus palustris Mill.)-slash pine (Pinus elliottii Engelm. var. elliottii) region of the South.

The first important effort to determine the relation between fire and wildlife habitat was reported by Stoddard (1931). He showed that frequent burning was necessary to maintain an adequate supply of food and cover for quail and turkey in the Flatwoods, and later (Stoddard 1936), that prescribed fire improved bobwhite quail habitat by increasing the quantity and availability of legume seed, particularly partridgepea (Cassia), beggarweed (Desmodium) and lespedeza (Lespedeza).

Vegetative response to burning in the 6.5 million

\footnotetext{
${ }^{1}$ Manuscript received 9 January 1975; accepted 4 August 1975.

"Present address: Silviculture Laboratory, USDA Forest Service, Bend, Oregon 97701 USA.

"Present address: Department of Fish and Game, Annapolis, Maryland 21401 USA.

${ }^{4}$ Present address: Forest Environmental Research, USDA Forest Service, Washington, D.C. 20250 USA.
}

hectare section of the Piedmont (Virginia to Georgia) which is occupied by loblolly pine (Pinus taeda L.) also indicates the desirability of prescribed burning to increase the availability of bird foods. Cushwa et al. (1966) and Cushwa and Redd (1967) compared herbaceous vegetation and seed production 1 and $2 \mathrm{yr}$ after burning in the Piedmont and found more herbs and seed on burned than on unburned plots, and more seed on plots burned during the summer than during the winter. Dense patches of these legumes can be created in the Piedmont by cutting and burning areas of poorest pine production (Cushwa et al. 1971).

Thus, burning in the southeastern United States increases both the number of plants and seed production from many herbaceous legumes; these seed are important quail and turkey foods. But many of these legumes commonly produce hard seed capable of remaining dormant but viable for a long time (Ewart 1908). Therefore, it is in the interests of improved habitat management to learn more about possible relationships between prescribed burning and germination of seed from these important wildlife food plants. Accordingly, the present study was conducted to determine the influence of heat on germination of 18 species of leguminous seed.

\section{Previous Work}

For many years researchers thought an outer layer of palisade cells in the seed coat was the impermeable portion of the seed in several species of legumes (Raleigh 1930, Watson 1948). Waxy or pectic materials associated with these cells were found to be excluding water.

Methods developed to break down, remove, or otherwise increase the permeability of the legume seed coat included scarification with sand paper (Hopkins 1923), soaking seed in sulfuric acid (Meginnis 1937) and in hot water (McNair 1917), or exposing seed to heat (Lute 1927, Rincker 1954). 


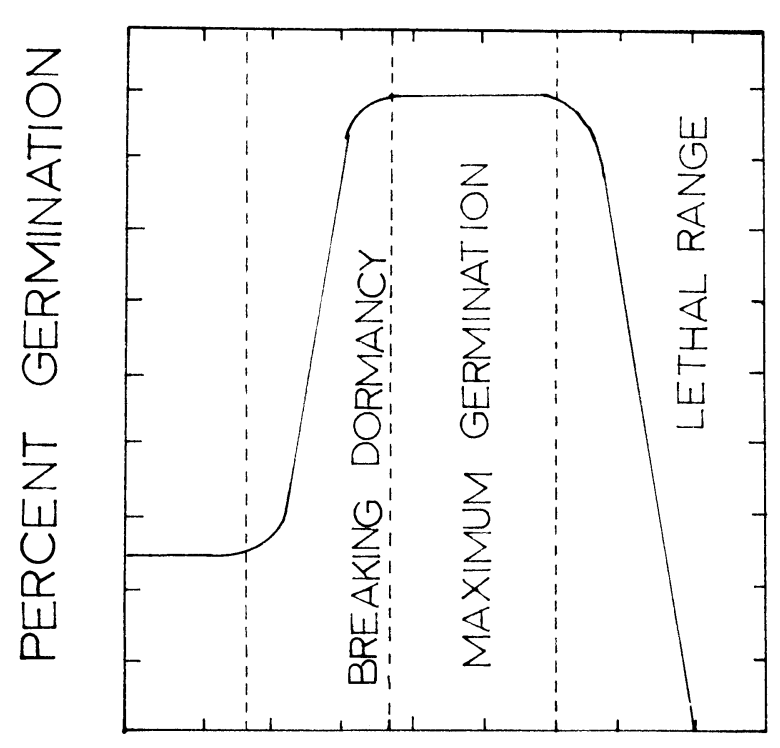

\section{TEMPERATURE ${ }^{\circ} \mathrm{C}$}

FIG. 1. Hypothetical germination curve of hard seeds in which dormancy is broken. (Martin and Cushwa 1966).

L. E. Foote and J. A. Jackobs (1966, unpubl. data) found that boiling Cassia fasciculata Michx. seed for 15-60 s softened the seed coat and increased germination. They also found that nicking seed with a razor blade was effective in increasing germination.

Martin and Cushwa (1966) conducted exploratory work on the effects of fire and heat on legume seed germination. They hypothesized that exposure to heat would increase germination of hard legume seed, and therefore, developed a hypothetical germination curve (Fig. 1), which included a range of low germination, a range where germination increases rapidly with temperature, a range of constant high germination, and finally a range where germination decreases rapidly as temperature increases.

They found that with several species of legumes, dry heat did not increase germination. These investigators reasoned that moisture was available from thermal degradation and combustion of woody fuels and from moisture present in the subfuels. Moist heat was, therefore, thought to simulate more nearly conditions in a forest fire than dry heat.

\section{Methods}

Seed of 18 species and two varieties of legumes were subjected to moist and dry heat treatments to measure germination response. Three replications of 100 seeds were used for each test when available. However, due to a limited supply of several species, the number of seeds had to be reduced to 50 per replication. Heat treatment exposures of $4 \mathrm{~min}$ were selected because this time is comparable to the time interval that heat effects from a prescribed fire (burning pine needle and herbaceous fuels) would be present at a given point on the forest floor (Martin $1963 a, b)$.

Moist heat treatments involved placing seed in a wire basket suspended above an enclosed water bath. Humidity was maintained at $100 \%$ by placing an insulated cover over the water bath. Dry heat treatments were accomplished using a modified oven to permit rapid insertion and removal of a wire basket containing the seed without disturbing the oven temperature. In both moist and dry heat treatments, we monitored temperatures during each exposure period. We determined germinations by placing seeds between moistened blotters in plastic petri dishes stored at room temperature and making periodic counts over a 33-day period. We remoistened blotters with distilled $\mathrm{H} . \mathrm{O}$ when necessary. A seed was considered to have germinated when the radicle emerged through the seed coat.

An analysis of variance was used to determine the effect of temperature treatments for each species. When significant differences were found, Duncan's New Multiple Range Test was used to determine the points along the temperature scale where the differences occurred. Minimum temperature necessary to break dormancy of a species was the lowest temperature treatment which resulted in significantly higher germination than that of untreated seeds (controls).

\section{RESUlts AND Discussion}

Eight of the 18 species tested showed a highly significant increase $(p<0.01)$ in germination when subjected to moist or dry heat treatments compared with germination of untreated seed (Table 1). Moist heat treatments increased germination in eight species, and dry heat increased germination in seven species. In addition, varieties of Lespedeza daurica and Lespedeza hirta responded significantly to dry and moist heat treatments.

Five of the 11 species of Lespedeza tested showed a highly significant increase in germination when subjected to either moist or dry heat treatments. Germination in one additional species, Lespedeza japonica, increased by dry heat but not by moist heat. Three Lespedeza species exhibited statistically higher germination following dry heat than after moist heat, whereas two Cassia species and one Lespedeza variety exhibited statistically higher germination after moist heat than after dry heat.

Dormancy of Lespedeza seed broke with greatest frequency as temperatures reached or exceeded $60^{\circ} \mathrm{C}$ with both moist and dry heat (Fig. $2 a-f$ ). Dormancybreaking temperatures ranged from $45^{\circ} \mathrm{C}$ to $80^{\circ} \mathrm{C}$ 

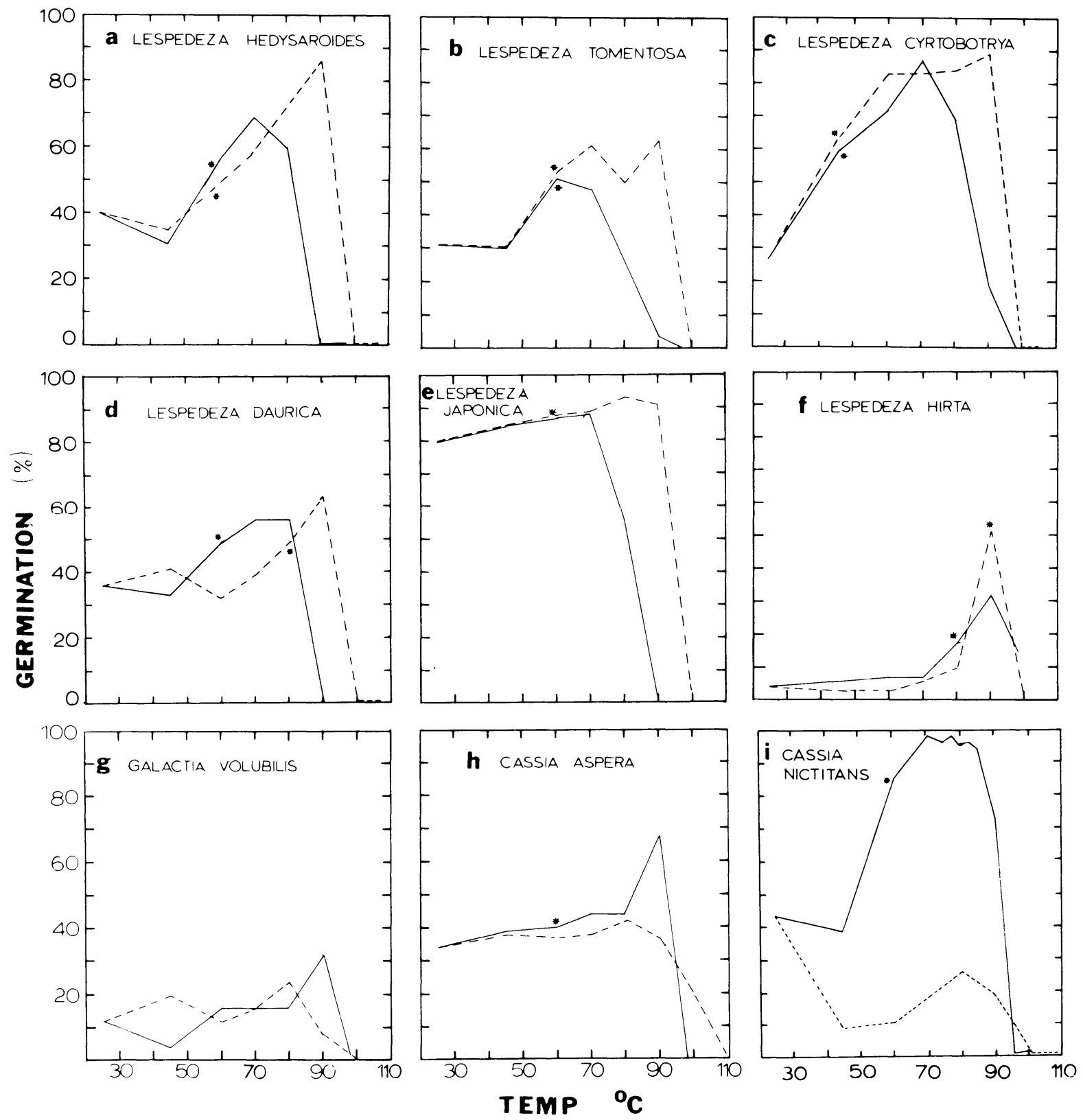

FIg. 2. The effect of 4 min exposure to moist (straight line) and dry (broken line) heat treatments on the germination of various legume seeds. Only those species are shown where heat treatment significantly increased germination above that of the control, the point of statistically significant difference being marked with an asterisk. Germination of control seeds is shown as the $25^{\circ} \mathrm{C}$ temperature germination.

for moist heat and from $45^{\circ} \mathrm{C}$ to $90^{\circ} \mathrm{C}$ for dry heat treatments. Maximum germination occurred with greatest frequency at $70^{\circ} \mathrm{C}$ for moist heat treatments, and at $90^{\circ} \mathrm{C}$ for dry heat treatment. In addition, the increase in germination following dry heat exposure seemed slightly higher than the increase following moist heat exposure.

Seed samples from three species of Desmodium did not contain hard seed. Over $90 \%$ germination occurred in two species using untreated seed. Germination in the third species did not increase in moist or dry heat.

Because of the limited number of Galactia volubilis seed available, we tested only one replication at each temperature. Both moist and dry heat appeared to enhance germination (Fig. $2 g$ ) ; however, we did not statistically analyze the results due to lack of replications. 
TABLE 1. Average germination percentages of legume seeds for control (no treatment) and for moist and dry heat treatments. For treated seeds, average germination for the temperature where highest germination occurred is given. $\mathrm{NS}=$ not significant

\begin{tabular}{|c|c|c|c|c|}
\hline \multirow[b]{2}{*}{ Species } & \multirow[b]{2}{*}{ Control } & \multicolumn{2}{|c|}{ Treatment } & \multirow{2}{*}{$\begin{array}{l}\text { Moist and dry heat } \\
\text { treatment response } \\
\text { significantly different } \\
\text { at this level of } \\
\text { probability }(\%)\end{array}$} \\
\hline & & Moist & Dry & \\
\hline & - - & --1 & minati & $-----\cdots$ \\
\hline Cassia aspera (Muhl.) Green. & 34 & $67 * *$ & 42 & 99 \\
\hline Cassia fasciculata Michx. & 0 & 3 & 1 & NS \\
\hline Cassia nictitans $\mathrm{L}$. & 44 & $98 * *$ & 26 & 99 \\
\hline Desmodium cilare (Muhl.) DC. & 97 & 100 & 97 & NS \\
\hline Desmodium cuspidatum (Muhl.) Loud. & 76 & 81 & 79 & NS \\
\hline Desmodium fernaldii Schub. & 91 & 92 & 91 & NS \\
\hline Galactia volubilis (L.) Britt. & 13 & $32^{a}$ & $24^{a}$ & $\ldots-$ \\
\hline Lespedeza bicolor Turcz. & 64 & 69 & 69 & NS \\
\hline Lespedeza capitata Michx. & 70 & 79 & 80 & NS \\
\hline Lespedeza cuneata (Dumont) G. Don. & 88 & 91 & 93 & NS \\
\hline Lespedeza cyrtobotrya Miq. & 27 & $87 * *$ & $89 * *$ & NS \\
\hline Lespedeza daurica Schindl. & 36 & $56 * *$ & $62 * *$ & NS \\
\hline Lespedeza daurica Schindl. var. schimidae & 56 & $78^{* *}$ & $71^{* *}$ & 95 \\
\hline Lespedeza heysaroides (Pall.) Kitagawa & 40 & $69 * *$ & $86 * *$ & 95 \\
\hline Lespedeza hirta (L.) Hornem & 5 & $33 * *$ & $51 * *$ & 95 \\
\hline Lespedeza hirta (L.) Hornem var. curtissii & 2 & $16^{* *}$ & $17 * *$ & NS \\
\hline Lespedeza intermixta Makino & 73 & 78 & 86 & NS \\
\hline Lespedeza japonica L.H. & 80 & 88 & $93 * *$ & NS \\
\hline Lespedeza tomentosa Siebod. & 31 & $51 * *$ & $63 * *$ & 95 \\
\hline Lespedeza virgata Nutt. & 59 & 65 & 63 & NS \\
\hline
\end{tabular}

** Indicates significantly higher germination from treated seeds than from control seeds $(p<0.01)$.

"Not tested for statistical significance due to lack of replication.

Germination of two of the three species of Cassia treated increased following moist heat treatments; however, dry heat did not increase germination in any of these seeds. Dormancy appeared to be broken in two species at $60^{\circ} \mathrm{C}$ (Fig. $2 h, i$ ) and maximum germination was obtained at $70^{\circ} \mathrm{C}$ for Cassia nictitans and at $90^{\circ} \mathrm{C}$ for Cassia aspera.

The causes of failure to absorb water are different in various subfamilies of the Leguminosae (Barton 1965). Our results indicate considerable variation in germinative response to heat treatments among genera and species, with some species responding to dry or moist heat, or both, or not responding to either. The seed coat may be impervious due to its chemical and physical properties. Apparently dry and moist heat modified substances in the seed coats of several species of Lespedeza which responded to either treatment. Species of the genus Cassia may have a seed coat which was altered or removed by moist heat but not by dry heat.

Dry or moist heat exposure for $4 \mathrm{~min}$ in the range of $90^{\circ} \mathrm{C}-110^{\circ} \mathrm{C}$ appears to be lethal to all seed tested. It is possible that a secondary dormancy was imposed, although we did not conduct specific tests to verify viability of the seed exposed to high temperatures.

\section{SumMARY AND CONClusions}

Eighteen species of legume seeds were subjected to moist and dry heat treatments. Moist heat increased germination in eight species, and dry heat increased germination in seven species. The seed coat appeared to be the factor responsible for excluding water and maintaining dormancy.

Laboratory tests indicate that moist heat similar to conditions produced during a forest fire may scarify hard seeds from several species of leguminous plants which are important quail food. Although we did not make a direct simulation of forest fire temperatures and moisture conditions, conditions approached those given by Martin $(1963 a, b)$ and Martin et al. (1969). Future work should reveal the combination of field conditions for a fire that produces heat and moisture conditions for optimum germination of seed from important quail food plants.

\section{ACKNOWLEDGMENTS}

This research was supported in part by the Southeastern Forest and Range Experiment Station, USDA Forest Service.

\section{Literature Cited}

Barton, L. V. 1965. Dormancy in seeds imposed by the seed coat. Encycl. Plant Physiol. 15:727-745. 
Cushwa, C. T., E. V. Brender, and R. M. Cooper. 1966. The response of herbaceous vegetation to prescribed burning. U.S. For. Serv. Res. Note S.E. 53. 2 p.

Cushwa, C. T., R. E. Martin, and M. L. Hopkins. 1971. Management of bobwhite quail in pine forests of the Atlantic Piedmont. Ga. For. Res. Pap. 65. 5 p.

Cushwa, C. T., and J. B. Redd. 1967. One prescribed burn: Its effects on habitat on the Powhatan Wildlife Management Area. Va. Wildl. 28:19.

Ewart, A. J. 1908. On the longevity of seeds. R. Soc. Victoria Proc. 21:1-210.

Hopkins, B. F. 1923. The behavior of hard seeds of certain legumes when subjected to conditions favorable to germination. Proc. Assoc. Seed Anal. North Am. 1923:46-48.

Lute, A. M. 1927. Alfalfa seed made permeable by heat. Science 65:166.

McNair, A. D. 1917. Boiling buffalo clover seed. Science 45:220-221.

Martin, R. E. 1963a. Thermal and other properties of bark and their relation to fire injury of tree stems. Ph.D. Thesis. Univ. Michigan, Ann Arbor. 256 p.

1963b. A basic approach to fire injury of tree stems. Proc. Annu. Tall Timbers Fire Ecol. Conf. 2:151-162.
Martin, R. E., and C. T. Cushwa. 1966. Effects of heat and moisture on leguminous seed. Proc. Annu. Tall Timbers Fire Ecol. Conf. 5:159-175.

Martin, R. E., C. T. Cushwa, and R. L. Miller. 1969. Fire as a physical factor in wildland management. Proc. Annu. Tall Timbers Fire Ecol. Conf. 9:271-288.

Meginnes, H. G. 1937. Sulfuric acid treatment to increase germination of black locust seed. U.S. Dep. Agric. Circ. 463.

Raleigh, G. T. 1930. Chemical conditions in maturation, dormancy, and germination of seeds of Gymnocladus dioca. Bot. Gaz. 89:273-294.

Rincker, C. M. 1954. Effect of heat on impermeable seeds of alfalfa, sweet clover, and red clover. Agron. J. 46:247-250.

Stoddard, H. L. 1931. The bobwhite quail: Its habits, preservation and use. Charles Schribner's Sons, New York. 359 p.

1936. The bobwhite quail. Charles Scribner's Sons, New York. 559 p.

Watson, D. P. 1948. Structure of the testa and its relation to germination in the Papilionaceae Tribes Trifoliae and Loteae. Ann. Bot. (Lond.) 12:385409. 